\title{
GIFTED STUDENTS AND HUMAN CAPITAL ACCUMULATION
}

\author{
Hana Lipovská ${ }^{1 \bowtie}$, Jakub Fischer $^{2}$ \\ ${ }^{1 凶}$ Department of Economics, Faculty of Economics and Administration, Masaryk University, Lipová 41a, Brno, 602 00, Czech Republic, \\ +420 723741 383, lipovska@mail.muni.cz \\ ${ }^{2}$ Department of Economic Statistics, Faculty of Informatics and Statistics, University of Economics, Prague, Czech Republic
}

Highlights
- $\quad$ The level of the human capital is influenced by the intergenerational transmission
- $\quad$ Gifted students came from the families with high level of the human capital
- $\quad$ Families play more important role than schools in the gifted student's development

\section{Abstract}

The economic growth and well-being of the nation increasingly depends on the human capital. In our study we offer original findings based on our survey Talent 2016. We try to identify who the talented students are, which background they did come from and how the family background influenced them. Our paper provides clear evidence of human capital intergenerational transmission. The vertical immobility in the same generation as well as the vertical mobility between generations was observed. Most of the gifted students came from the complete highly educated families with tradition in their field of interest and long positive attitudes toward accumulating the knowledge. Contrarily, the role of the teachers in the support and guidance is negligible. We have shown that there is close relation between the gifted children premature reading ability and the accumulation of the human capital in their families. The same is valid for the attendance of the 8-years grammar schools. Based on our dataset, we do not observe the Galtonian regression toward the mean. For the future economic growth there must be offered a helping hand for the talented children with less educated family background.

\section{Keywords}

Gifted students, human capital, intergenerational transmission, responsibility in education, Talent 2016 survey

\section{Introduction}

The economic growth as well as well-being of the nation depends increasingly on the human capital (e.g. Benos and Karagiannis 2016). As Callard-Szulgit (2012: 19) mentions, the promise of our future is especially the human capital of the gifted students. According to Rinn and Bishop (2015), the gifted children become gifted adults - and they can promote the economic growth of their country. Kell, Lubinski and Benbow (2013: 1) add that 'being able to identify, attract, and develop human capital is increasingly critical for business, scientific, and technical organizations as they strive for a competitive edge'. If the gifted children cannot do their best, if their valuable human capital is 'unemployed', the massive wasting of this rare source leads to the underachievement of the whole economy (compare Yeung 2012).

However, if we study the background of the most talented and gifted personalities, we often find that there is high level of accumulated human capital across the generations (e.g. Yang and Qiu 2016). Parents with higher education levels have children with higher education levels (Black, Devereux and Salvanes 2003). Parental educational level also affects the lifelong learning of adults (Fischer and Lipovská 2013a). The crucial question is, if the highly gifted students came from families with the high accumulated level of education as well as from the families with the lower (or even the lowest) education level or, on the contrary, if the gifted children from the poorer and less educated families hit the glass ceiling and do not have enough chances to further cultivate their human capital.
If the intergenerational transmission mechanism of the human capital worked strongly among the gifted children and their families, it should be the school and teachers, who distinguish the student's potential and help to cultivate his or her talent. Recent Czech schooling policy supports especially disadvantaged children and children with learning disabilities. Characteristically, in the Act no. 103/2014 Coll. amending Act no. 73/2005 Coll., on the education of children, pupils and students with special educational needs and exceptionally gifted, just two sections are devoted to the exceptionally gifted, while ten sections deal with the disadvantaged students.

According to the Czech School Inspection Report (Entler, Sosnovec and Šecl 2008) only one third of all Czech schools clearly identify their gifted and talented students. Moreover, the work with such students is not systematic. It mostly consists just of the participation at competitions, as the schools are not motivated to take care of gifted children. Matěju (2006) claims that even the grammar schools 'does not act as an instrument of upward educational mobility', but - on the contrary - their just promote the 'intergenerational reproduction of educational inequality'.

As Ermisch, Pronzato (2010), Sewell, Shah (1968) or Fischer, Lipovská (2013b) mention, there is the sex-dependency in the intergenerational transmission mechanism. Similarly there is a consensus that children from complete families do better than their counterparts from divorced families (e.g. Pavlát 2011). 
Widely discussed among in the intergenerational transmission research is the Galtonian regression to the mean (e.g. Senn 2011). The question is, if the above-average achievements of the one generation are sustainable (or even better: promoted) in the following generations or if they just regress to the mean. In other words: are the gifted students products of the long academic dynasties rich in the human capital or are they just the random successes in the game of genes?

The aim of this paper is to identify who the talented students are and from which background they did come. To do this we conducted unique survey among the most successful and talented students in the Czech Republic (and especially in the South Moravian Region, which has consistent program for cooperation with talented students since 2003). This paper stems from previous conference paper Lipovská and Fischer (2016) which it extends substantially. While the conference paper used merely the instruments of the descriptive statistics, in this paper the more advanced statistical methods are used. Furthermore, the findings of the new research on the premature reading and writing as well as the eight-year grammar school attendance were added. The most important innovation consists of the research on the human capital accumulation which is supported by the original statistical method.

The rest of the paper is organized as follows. We introduce the survey, data and methods we used and we explain usage of the crucial terms gift and talent. Then the results of our analysis are presented. Firstly we analyse the intergenerational transmission mechanism from the grandparents to the parents of talented students, as well as their working status. Secondly we explore, who has the greatest effect on the talented students, who brought them to their field of interest and who supports them. Then the self-evaluation of the talented students is examined. In the following chapters the premature reading and writing as well as the 8-year grammar school attendance is studied. Further, the Galtonian regression to the mean is discussed. Finally, we deal with the human capital accumulation over three generations in the talented student's families.

\section{Materials and Methods}

Our research is based on unique dataset Talent 2016. This survey was conducted from $24^{\text {th }}$ January to $31^{\text {st }}$ January 2016 among highly talented students in the Czech Republic. On-line questionnaire was sent to two groups of respondents:

i. All current and former participants of the Support for Talented High School Students (PPNS) managed by the South Moravian Centre for International Mobility (JCMM). These students or former participants enrolled to the program either because of the outstanding results at national or international level of student's competition, or according to the assessment in educational and psychological consulting.

ii. All participant of national round of Students Professional Activities in 2015 (almost 300 respondents). These students are winners of regional levels, which means that they were able to write during their secondary education professional thesis on the scientific topics. On-line questionnaires were distributed via the National Institute for Further Education.

Both groups overlapped in certain range as some of the successful Student Profession Activities Competition are participants at JCMM PPNS program. Totally 213 questionnaires were fully filled and therefore filed to the final dataset. Even if the pessimistic scenario of no data-overlapping was taken into the account, the minimum response rate exceeded $41 \%$, which is far better than in case of the standard surveys. There was $60 \%$ of men and $40 \%$ of women in the dataset.

For comparison with the Czech standard education and occupation structure the results of Population and Housing Census 2011 were used. These data are available from the Czech Statistical Office official database. Similarly as in Fischer, Lipovská (2013b) we distinguished students with blue-collars parents and white-collars parents according to the ISCO-08 classification (see Table 1).

\begin{tabular}{|c|l|c|l|}
\hline \multicolumn{2}{|c|}{ white-collars workers } & \multicolumn{2}{|c|}{ blue-collars workers } \\
\hline 0 & armed forces occupations & 6 & $\begin{array}{l}\text { Skilled agricultural, forestry } \\
\text { and fishery workers }\end{array}$ \\
\hline 1 & Managers & 7 & $\begin{array}{l}\text { Craft and related trades } \\
\text { workers }\end{array}$ \\
\hline 2 & Professionals & 8 & $\begin{array}{l}\text { Plant and machine operators, } \\
\text { and assemblers }\end{array}$ \\
\hline 3 & $\begin{array}{l}\text { technicians and associated } \\
\text { professionals }\end{array}$ & 9 & Elementary occupations \\
\hline 4 & clerical support workers & \multicolumn{2}{|l}{} \\
\hline 5 & service and sales workers & \multicolumn{2}{|l}{} \\
\hline
\end{tabular}

Table 1: International Standard Classification of Occupations. White and blue collars workers distinction

Students were further asked to describe their subjectively greatest success. These verbal descriptions were subsequently classified according to the Table 2 .

\begin{tabular}{|c|c|c|}
\hline \multicolumn{2}{|c|}{ categories } & success level \\
\hline \multirow{3}{*}{ minor success } & 1. & personal \\
\cline { 2 - 3 } & 2. & local \\
\cline { 2 - 3 } & 3. & regional \\
\hline \multirow{2}{*}{ major success } & 4. & national \\
\cline { 2 - 3 } & 5. & international \\
\hline
\end{tabular}

Table 2: Classification of respondents' successes

\section{Gifted or talented?}

Psychological as well as pedagogical literature distinguishes between terms gifted and talented. However, the explicit definition of both concepts and their distinction is unclear. Table 3 summarizes examples of completely different meanings of both terms.

\begin{tabular}{|c|c|c|c|}
\hline \multicolumn{2}{|c|}{ Giftedness } & \multicolumn{2}{|r|}{ Talent } \\
\hline \multirow{2}{*}{$\begin{array}{l}\text { Makel } \\
\text { et al. } \\
(2015)\end{array}$} & $\begin{array}{l}\text { comes from } \\
\text { people }\end{array}$ & $\begin{array}{l}\text { Makel et } \\
\text { al. (2015) }\end{array}$ & can be developed \\
\hline & natural ability & \multirow{2}{*}{$\begin{array}{l}\text { Hartl } \\
(2000)\end{array}$} & $\begin{array}{l}\text { set of innate abili- } \\
\text { ties }\end{array}$ \\
\hline $\begin{array}{l}\text { Yeung } \\
(2014)\end{array}$ & $\begin{array}{l}\text { is effortless, not } \\
\text { earned }\end{array}$ & & revealed gift \\
\hline $\begin{array}{l}\text { Mudrak } \\
(2015)\end{array}$ & $\begin{array}{l}\text { unusual promise in } \\
\text { the learning }\end{array}$ & $\begin{array}{l}\text { Gallardo } \\
\text { (2013) }\end{array}$ & $\begin{array}{l}\text { natural ability } \\
\text { mastery } \\
\text { commitment }\end{array}$ \\
\hline $\begin{array}{l}\text { Hříbková } \\
(2009)\end{array}$ & \multicolumn{3}{|c|}{ Synonyms } \\
\hline
\end{tabular}

Table 3: Giftedness and Talent - comparison of various definitions (source: own elaboration) 
When using Google trends statistics, adjective gifted is used twice more often than adjective talented in English. On the other hand the Czech equivalent for talented ('talentovany') is more frequent than equivalent for gifted ('nadany'). As Gallardo (2013) notices, these terms can mean whatever writer wants it to mean.

We are well aware of the fact that the difference between talent and giftedness might be of vital importance in psychology or for the pedagogical science. Nevertheless, our study deals with the relationship of talent, gift and human capital, not with precious definition of these terms. In line with Hř́bková (2009) we can use both words as synonyms. This approach is even underlined by the OECD definition of human capital as the 'combination of the innate talent and individual abilities, skills and education' (Brian 2007).

\section{Human capital accumulation}

Qualitative variables used in the survey can be easily quantified if we assign to each level of education the standard length of the study program. Disadvantage of this approach is that it is not always the perfectly precious variable. The main weaknesses are:

- Some of the respondents and their family members might have skipped-of one or even more of the school years (e.g. they could study at the grammar school just 3 instead of 4 years) because of their extra-ordinary good performance.

- Furthermore, the standard length of the each educational level in the Czech Republic had been changing during the last decays. For example the primary education should take 8 years before 1948,9 years to 1953,8 years to 1960 , 9 years to 1978,8 years to 1990 and again 9 years since 1990 (e. g. Morkes 2010).

- Bachelor degree in some of the fields (especially the Civil Engineering) is often quadrennial while usual bachelor studies take only three years.

- Medical master's program takes six years instead of usual five years.

- Some of the doctoral programs are triennial, other quadrennial and finally the distance doctoral study program can take e. g. eight years.

However, we selected the length of each level in such way, as it responded to the recent equivalent of the standard program. Thus length is summed up in the Table 4.

\begin{tabular}{|c|l|c|r|}
\hline & \multicolumn{1}{|c|}{ Level of education } & Years & $\begin{array}{c}\text { Total length of edu- } \\
\text { cation (years) }\end{array}$ \\
\hline$a$ & Primary education & 9 & 9 \\
\hline$b$ & Lower secondary education & 3 & $(\mathrm{a}+\mathrm{b}) 12$ \\
\hline$c$ & Upper secondary education & 4 & $(\mathrm{a}+\mathrm{c}) 13$ \\
\hline$d$ & Short-cycle tertiary education & 3 & $(\mathrm{a}+\mathrm{c}+\mathrm{d}) 16$ \\
\hline$e$ & Bachelor's or equivalent level & 3 & $(\mathrm{a}+\mathrm{c}+\mathrm{e}) 16$ \\
\hline$f$ & Master's or equivalent level & 2 & $(\mathrm{a}+\mathrm{c}+\mathrm{e}+\mathrm{f}) 18$ \\
\hline$g$ & Doctoral or equivalent level & 4 & $(\mathrm{a}+\mathrm{c}+\mathrm{e}+\mathrm{f}+\mathrm{g}) 22$ \\
\hline
\end{tabular}

Table 4: Total length of education

The total length of the education was then calculated as the accumulation of all the standards educational level which the individual had to went through to reach the appropriate level.

Using the lengths listed in the Table 4 the short run and long run human capital accumulation was calculated. This concept (constructed for the very aim of our research) is based on the consideration, that the human capital level can be approximated with the number of years spent in the school system (e. g. Mazouch and Fischer 2011). First of all the total length of education was assigned to each of the talented student's ancestors (mother and father respectively). Then, the short run human capital accumulation $H C_{0}$ was calculated for student himself as

$$
H C_{0}=X_{1}+X_{2},
$$

When $X_{1}$ is number of years spent at school by students mother and $X_{2}$ is number of years spent at school by students father.

Similarly we calculated short run human capital accumulation $H C_{1}$ and $H C_{2}$ for student's mother and father:

$$
H C_{i}=X_{i 1}+X_{i 2}, i \in\{1,2\},
$$

When $X_{1 j}$ is number of years spent at school by maternal grandmother $(j=1)$ or parental grandmother $(j=2)$ and $X_{2 j}$ represents number of years spent at school by maternal grandfather $(j=1)$ or parental grandfather $(j=2)$.

Finally the long-run human capital accumulation $L H C$ was calculated for each talented student as

$$
L H C=\sum_{i=0}^{2} H C_{i} .
$$

The short-run human capital accumulation $H C_{j}, j \in\{0,1,2\}$ can take

- maximum $M A X=44$ if both parents reached the doctoral degree;

- minimum $M I N=18$ if both parents finished just the elementary school.

For more comfortable handling of these data we rescale the variable $H C_{j}$ to the scale $H C_{j}^{*} \in\langle 0,100\rangle$. In this case

$H C_{j}^{*}=0=M I N^{*}$ responses to the situation when both parents finished only the elementary school;

- $H C_{j}^{*}=100=M A X^{*}$ responses to the situation, when both parents reached the doctoral degree.

For the aim of rescaling we use the following formula (4):

$$
H C_{j}^{*}=100-\left(\frac{M A X^{*}-M I N^{*}}{M A X-M I N}\right) \times\left(M A X-H C_{j}\right) .
$$

In case of the short-run human capital accumulation the $H C$ can be computed as

$$
H C_{j}^{*}=100-\left(\frac{100-0}{44-18}\right) \times\left(44-H C_{j}\right) .
$$

Similarly the long-run human capital accumulation LHS can take

- maximum $M A X=132$ if both parents and all four grandparents reached the doctoral degree;

- minimum $M I N=54$ if both parents and all four grandparents finished only the elementary school.

The re-scaled variable $L H C^{*}$ is then computed as 


$$
L H C^{*}=100-\left(\frac{100-0}{132-54}\right) \times(132-L H C) .
$$

Figure 1 and 2 respectively depicts the absolute frequencies histogram of the short-run and long-run human capital of the talented students classified into the 10 class intervals of the with 10 .

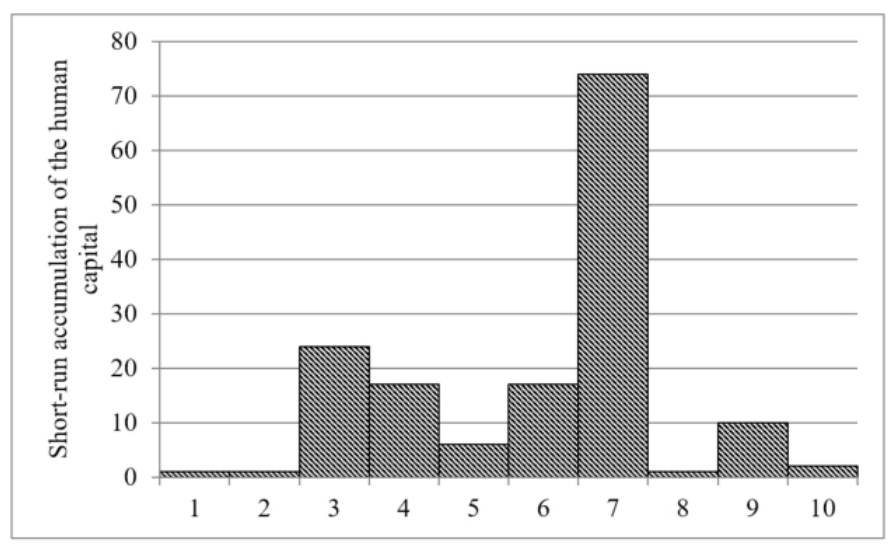

Figure 1: Histogram shows the distribution of the short-run accumulation of the talented student's human capital $\mathrm{HC}_{0}^{*}$ (source: own calculation)

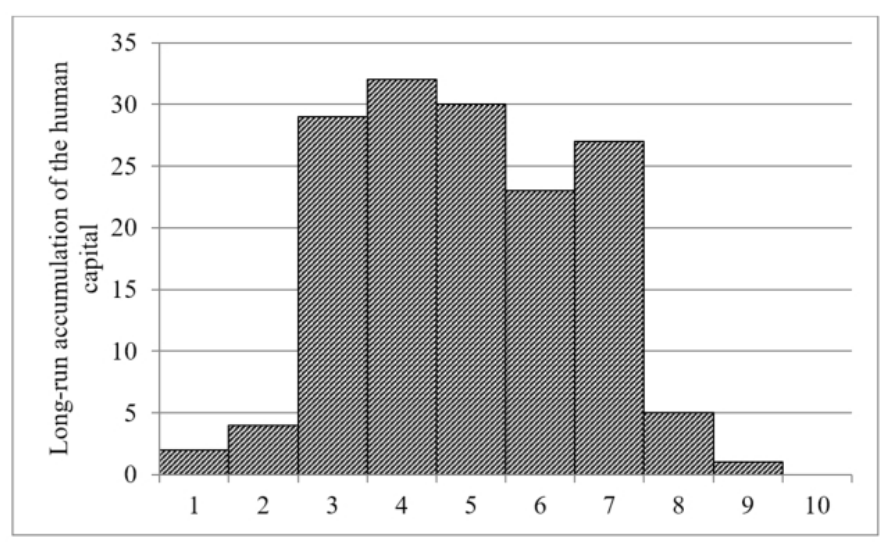

Figure 2: Histogram shows the distribution of long-run accumulation of the talented student's human capital $L H C^{*}$ (source: own calculation)

\section{Statistical methods}

For the aim of our research standard methods of the descriptive as well as mathematical statistic were used. In the first subchapter of chapter Results we use predominantly the arithmetic mean, frequency tables and Pearson's coefficient of correlation $\rho$. Determination of the correlation strength is subject of many discussions. In our paper we use the classification as presented in Table 5.

\begin{tabular}{|c|c|}
\hline Size of correlation coefficient & $\begin{array}{c}\text { Interpretation of the } \\
\text { relationship }\end{array}$ \\
\hline$\langle \pm 0.70 ; \pm 1.00\rangle$ & high \\
\hline$\langle \pm 0.30 ; \pm 0.69\rangle$ & moderate \\
\hline$\langle \pm 0.10 ; \pm 0.29\rangle$ & low \\
\hline$\langle \pm 0.00 ; \pm 0.09\rangle$ & none \\
\hline
\end{tabular}

Table5:Pearson'scoefficientofcorrelation:strengthoftherelationship (source: Jackson 2008: 42, own elaboration)

Hypothesis on the independence between nominal variables is tested using Pearson's $\chi^{2}$ test and the Pearson's K statistics.
The strength of this relation is measured by the Cramér's $V$ coefficient which is interpreted in line with the Table 6 .

\begin{tabular}{|c|c|}
\hline Size of the Cramér's $\boldsymbol{V}$ & $\begin{array}{c}\text { Interpretation of the } \\
\text { relationship }\end{array}$ \\
\hline$\langle \pm 0.30 ; \pm 1.00\rangle$ & high \\
\hline$\langle \pm 0.20 ; \pm 0.29\rangle$ & moderate \\
\hline$\langle \pm 0.10 ; \pm 0.19\rangle$ & low \\
\hline$\langle \pm 0.00 ; \pm 0.09\rangle$ & very low \\
\hline
\end{tabular}

Table 6: Cramer's $V$ coefficient: strength of the relationship (source: Botsch 2011, own elaboration)

Furthermore, the univariate Analysis of variance (ANOVA) based on the Scheffe's post-hoc test was used (see e.g. Budíková, Králová and Maroš 2010).

\section{Results}

In this section we firstly examined the human-capital background of the talented students in terms of the educational level of parents and grandparents as well as the field of their studies. Secondly we discuss the self-estimation of talented students and their own explanation of their success. In our dataset $60 \%$ of respondents were talented male students, $40 \%$ talented female students. Most of respondents (60\%) studied at eightyear grammar school $(85 \%$ of them having tertiary educated parents), $22 \%$ studied at four-year grammar school $(70 \%$ of them having tertiary educated parents) and only $18 \%$ at other type of secondary schools (only $26 \%$ of them having tertiary educated parents). More than one third of respondents gained the major (national or international) success (35\% of students). Those basic statistics are in line with the assumption postulated by Matěju (2006), as there is really just the accumulation, not the transmission of the human capital at the Czech grammar schools. In accordance with Pavlát (2011) most of the talented students $(88 \%)$ grew up in the complete families with both parents.

\section{Human capital and the family background}

As figure 3 clearly shows, the gifted students came from highly educated families. Nearly one half (49\%) of all respondents comes from families where both parents have the university degree, $71 \%$ come from families where at least one of the parents have the university degree. Moreover, 39\% of talented students come from the teacher's families.

If mother has the university degree, her father had the degree in $57 \%$ cases and her mother in $33 \%$ cases, at least one of her parents had the degree in $75 \%$ cases. On the other hand, if the mother did not get university degree, her mother studied the university just in $8 \%$ of cases and her father just in $18 \%$ of cases. Nevertheless, $77 \%$ of these mothers reached an upper secondary education.

This transmission mechanism is slightly weaker in the father's families, where the education of mothers from the father side is the same as in case of mothers, but fathers are significantly less educated (only $48 \%$ had a degree). At least one of his parents had the degree in $70 \%$ cases. On the other hand, if the father did not get university degree, his mother studied the university just in $4 \%$ of cases and his father just in $9 \%$ of cases. Those results 
are in line with the sex-dependency as described in Fischer and Lipovská (2013) or Ermisch and Pronzato (2010).

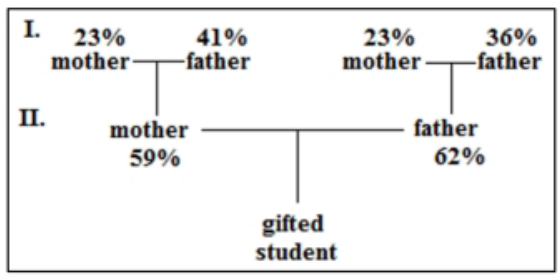

Figure 3: Ratio of the gifted students' family members, who got university degree (source: own calculation)

According to the Population and Housing Census 2011, only $17 \%$ of all economically active Czech citizens have the tertiary education. In case of the gifted student's families even the generation grandparents reached above-average level of education (compare figures 4 and 5). Apparently the intergenerational transmission mechanism works among talented-students families in the same way as described by Becker (1993).

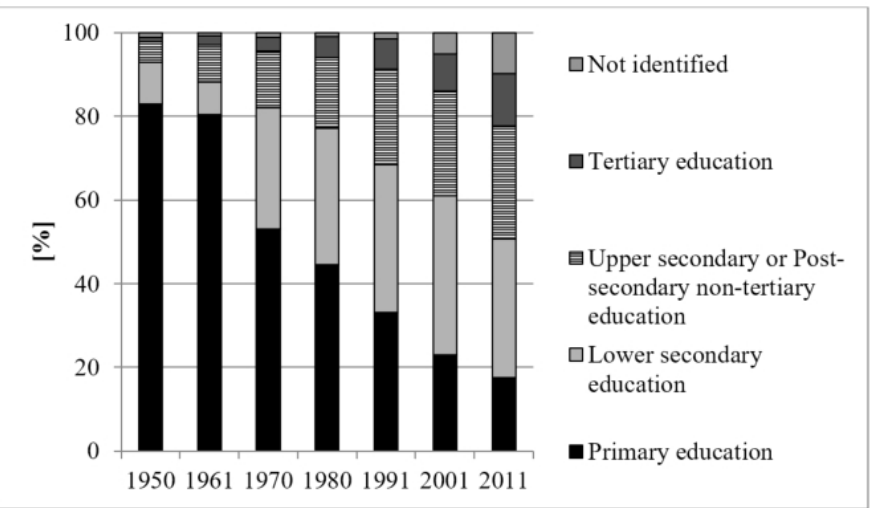

Figure 4: Development of the educational structure in the Czech Republic in 1950-2011 (source: CZSO 2014, own elaboration)

According to the results of Population and Housing Census $2011,64 \%$ of economically active citizens work at the whitecollars occupations. This ratio is significantly higher for the families of talented students: $94 \%$ of mothers and $82 \%$ of fathers are white-collars workers.

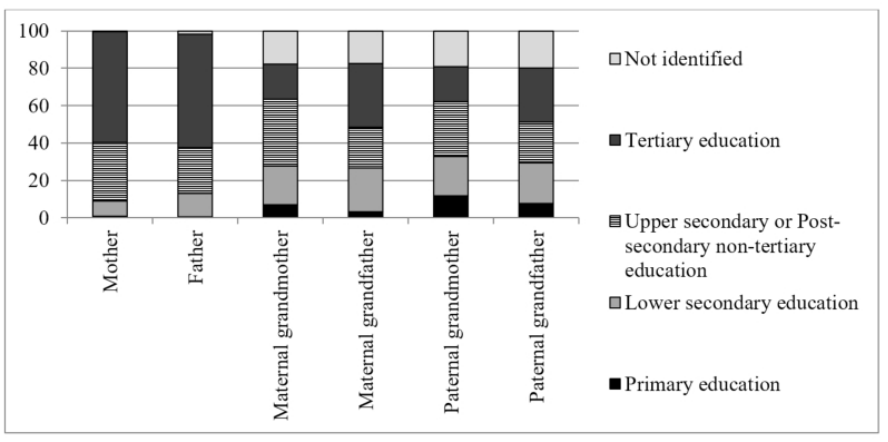

Figure 5: Educational structure in the gifted student's families (source: own calculation)

If we restrict our dataset just to those respondents, who study or studied at university, we find, that

- a fifth of talented students major in the same field as their mothers;

- $\quad$ one third major in the same field as their fathers;

- one half has the same professional orientation as at least one of the family members (including the grandparents).
As Table 7 clearly shows, there is strong relation between the field of fathers and grandfather as well as between mothers and grandmothers. Significantly high number of talented male students inherited their field from their fathers. On the other hand the relationship between the field of talented female students and field of their parents is somewhat weaker.

\begin{tabular}{|l|l|c|c|}
\hline \multicolumn{2}{|c|}{} & mother & father \\
\hline \multirow{3}{*}{ Talented student } & female-student & $20 \%$ & $18 \%$ \\
\cline { 2 - 4 } & male-student & $22 \%$ & $43 \%$ \\
\hline \multirow{2}{*}{$\begin{array}{l}\text { Talented } \\
\text { student's parents }\end{array}$} & talented student's mother & $33 \%$ & $10 \%$ \\
\cline { 2 - 4 } & talented student's father & $8 \%$ & $25 \%$ \\
\hline
\end{tabular}

Table 7: After who did the talented students and their parents inherited the field of interest?

When asked who brought them to the field in which they excel, most of the talented students $(68 \%)$ claims, that their find their way themselves. ${ }^{1}$ Most often this was the response of students whose parents lacked the tertiary education (78\% chosen the option 'I've found this field on my own') against students from tertiary educated families $(57 \%)$. Great deal of students also mentioned that they were brought to their field by family members. This impact is stronger especially if the parents have tertiary education.

As Table 8 shows, parents with tertiary education brought talented students to their field twice more often. Again, there is a strong sex-dependency: talented female-students were influenced more often by their mothers $(28 \%)$ than male-students $(15 \%)$. On the contrary, talented male-students were influenced more often by their fathers $(38 \%)$ than the female-students $(25 \%)$. Only $8 \%$ of students stated, that their field selection was influenced by their elementary school teacher and $18 \%$ by their high school teacher. What is more, there is no evidence, that the teachers would influence talented students from the lower-educated families more than talented students from higher-educated families. Those results are in line with the findings of Czech School Inspection (Entler, Sosnovec and Šecl 2008).

\begin{tabular}{|l|c|c|}
\hline & Mother & Father \\
\hline Tertiary education & $25 \%$ & $40 \%$ \\
\hline Lower than tertiary education & $13 \%$ & $19 \%$ \\
\hline
\end{tabular}

Table 8: Parental influence on the field selection according to their level of education

\section{Self-estimation and cause of success}

More than half of talented students consider themselves as above-average during their secondary education (57\%) as well as during their primary education (52\%). However, while $76 \%$ of talented male-students consider themselves as above average, the same is valid just for $45 \%$ of talented female students. This finding confirms existence of female confidence gap among the top professionals as described e.g. in Sarsons and Xu (2015). Similarly students from higher educated families estimated themselves better than students from lower-educated families (61\% as compared with $48 \%$ student from lower-educated families).

Most of the talented students explain their success by their interest in the field $(69 \%)$ and diligence $(54 \%){ }^{2}$ On the other hand just $29 \%$ of them explained their success by the support

1 Respondents could select multiple options.

2 Respondents could select multiple options. 
of their teachers (in contrary to $42 \%$ of talented students who mentioned the importance of their parental support).

As figure 6 clearly depicts, the interest in field is the most often explanation of the male-students success $(75 \%)$, while the female-students highlights especially their endurance $(67 \%)$. Talented students who reached the major success on the national or international level mention especially their diligence $(77 \%$ of them) and endurance (59\% of them).

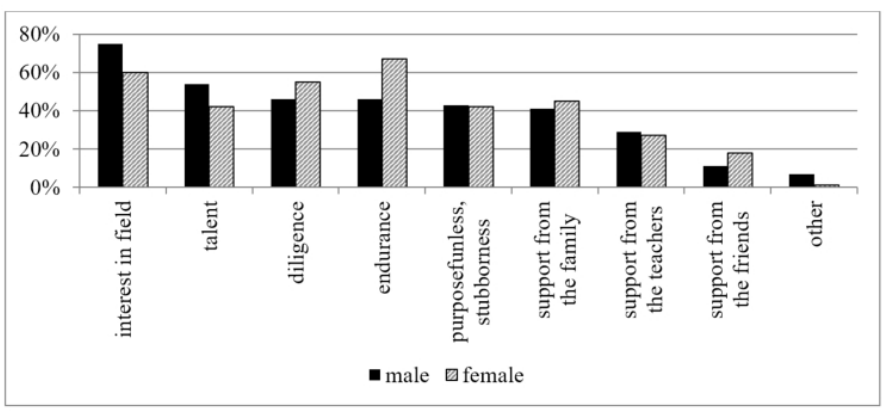

Figure 6: What do you consider to be the main reason for your success? (Respondents by gender)

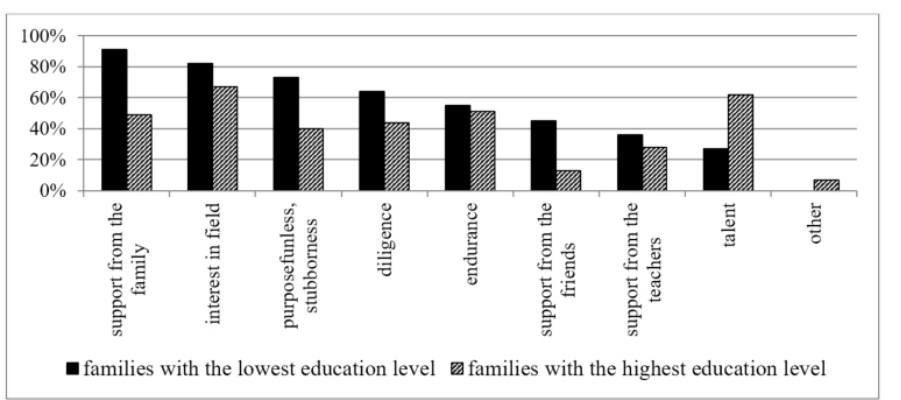

Figure 7: What do you consider to be the main reason for your success? (Respondents by educational level of their families)

There are large differences between the success-factors consideration among the talented students from the lower and higher educated families. While $58 \%$ of talented students from higher-educated families stressed their talent, only $27 \%$ of talented students from the lower-educated families considered talent as an important factor. Similarly, talented students from the higher-educated families mentioned importance of their parental support more often than students from lower-educated families ( $48 \%$ in comparison to $29 \%$ ). On the other hand, students from the lower-educated families find their diligence as more important than students from the higher-educated families (56\% in comparison to $46 \%$ ) and their stressed also the importance of the field interest (74\% in comparison to $67 \%$ of talented students from the higher-educated families).

The greatest differences in the success explanation might be observed between the talented students from the families with both tertiary-educated parents and families with none of the tertiary educated parents. Talented students from the lowesteducated families extraordinary stress the role of their family support ( $91 \%$ of them in comparison to only $49 \%$ of students from the families with the highest human capital level). Compared to that, talented students from the highest educated families extremely highlighted the effect of their talent $(62 \%$ in comparison to only $27 \%$ of students from the families with the lowest human capital level, see figure 7). This is in line with Winner (1997:185) who says that "There are poor and undereducated families who value education and achievement, just as there are many upper-income families, who do not provide enriching environments, and allow their children to spend the bulk of their time in front of the television or at the mall."

\section{Premature reading and writing: evidence of talent}

When entering the first class of the elementary school, $54 \%$ of gifted students could read. More often was that valid for male students $(56 \%)$ than for female students (49\%). Read and write could $35 \%$ of gifted children. Nevertheless, if at least one of the parents has tertiary education, this share increases to $41 \%$. On the other hand, if none of the parents has tertiary education, only $19 \%$ of the gifted students could read and write before starting the school.

Respondents, who evaluate themselves as gifted already from the elementary school, could read before starting the school more often than those, who consider themselves not being gifted already from the elementary school (44\% versus $20 \%$ ).

The impact of family human capital background is impressive. Figure 8 depicts, that if all ancestors ${ }^{3}$ of the gifted students gained the university degree, $82 \%$ of gifted students could read before entering the elementary school. If at least one of the parents gained the university degree, $60 \%$ of gifted could read before entering the elementary school. However if none of the parents gained the university degree $60 \%$ of gifted could not read before entering the elementary school.

Among the students who graduated from the 8-years grammar school $61 \%$ could read before entering the elementary school. The same is truth just for the $36 \%$ of graduates from the Specialized secondary schools and $48 \%$ of the graduates from the standard 4-years grammar schools.

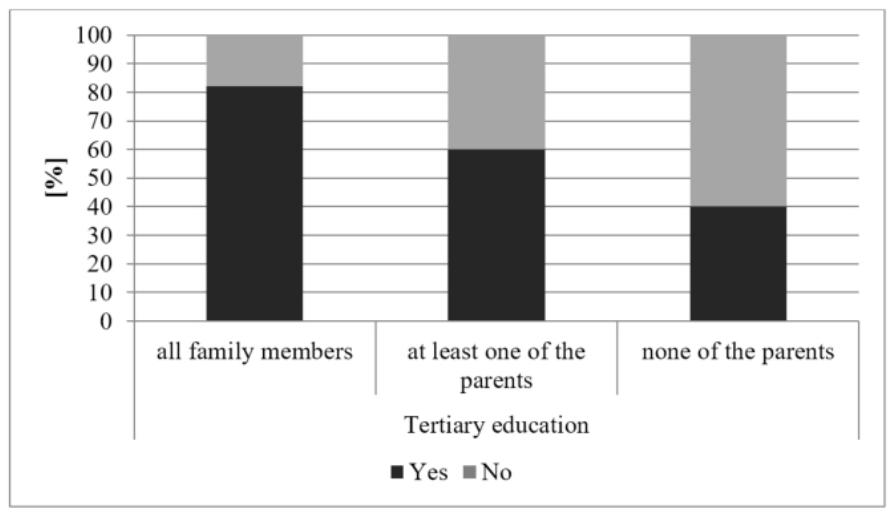

Figure 8: Could you read before entering the elementary school? (Respondents by educational level of their families)

Gifted students at the eight-year grammar schools Using the $\chi^{2}$ test the following null hypothesis was tested:

\section{$H_{0}:$ Tertiary education of the parents and gifted children} attendance of the 8-years grammar school are independent.

The null hypothesis was rejected at the 5\% significance level in favour to alternative that there is strong relationship between the university degree of parents and attendance of the 8-years grammar school of their gifted children. Cramér's $V$ coefficient is 0.36 .

Moreover, the analysis of variance proved that this relationship is not only very strong, but also strictly positive. Nearly $3 / 4$ 
of gifted children from the families with at least one tertiary educated parent entered the 8-years grammar school, while the same is truth for only $30 \%$ of children from families without any university degree (see figure 9).

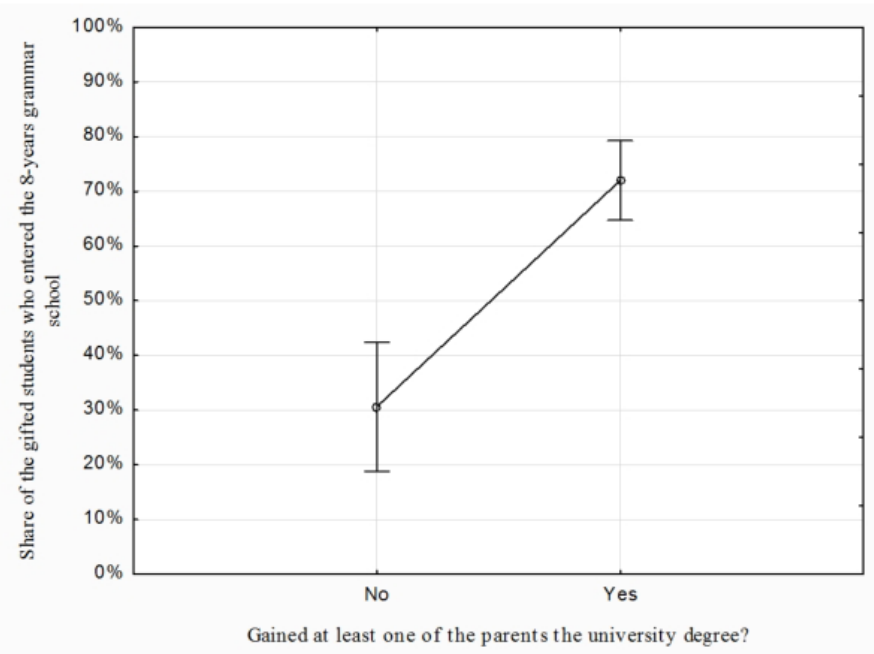

Figure 9: Relationship between tertiary education of parents and gifted student's attendance of the 8-years grammar school. Confidence interval plot $(95 \%)$

\section{Galtonian regression}

As for the inequality in the opportunities the vertical mobility is of the vital importance. In this subchapter we ask if the parents of the gifted students reached higher level of the human capital than their own parents.

On average, the mothers and fathers gained higher level of human capital than their parents. However, in both generations fathers gained higher human capital level than mothers. While mothers studied 2.2 years longer than their own mothers and 1 year longer than their own fathers, fathers studied 2.3 years longer than their own fathers and 3.1 years longer than their own mothers (see figure 10).

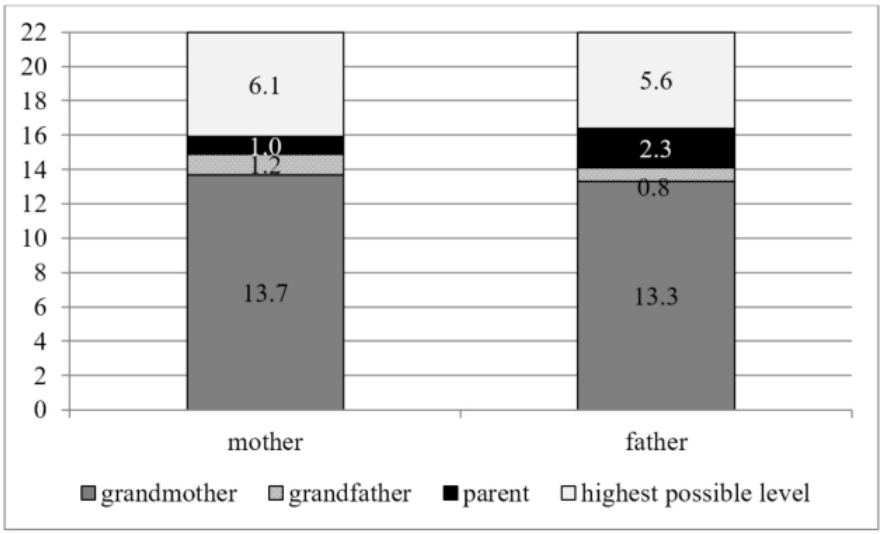

Figure 10: Accumulation of the human capital among maternal and parental families

As it is summed up in the Table 9, 90\% of mothers gained at least the same or higher level of human capital as their own mothers and $82 \%$ gained the same or even higher level as their own fathers. Vertical mobility was proved for $60 \%$ mothers of the gifted students.

The same pattern is even more pronounced for fathers: $95 \%$ of gifted student's fathers gained at least the same or higher level of human capital as their own mothers and $94 \%$ gained the same or even higher level of human capital as their own fathers. Vertical mobility was proved for $65 \%$ fathers of the gifted students.

\begin{tabular}{|c|c|c|c|c|}
\hline \multicolumn{2}{|c|}{} & grandmother & grandfather & $\begin{array}{c}\text { grandparent's } \\
\text { average }\end{array}$ \\
\hline \multirow{4}{*}{ mother } & $<$ & 10 & 18 & 18 \\
\cline { 2 - 5 } & $=$ & 34 & 41 & 22 \\
\cline { 2 - 5 } & $>$ & 56 & 41 & 60 \\
\hline \multirow{4}{*}{ father } & $<$ & 5 & 6 & 9 \\
\cline { 2 - 5 } & $=$ & 34 & 42 & 26 \\
\cline { 2 - 5 } & $>$ & 61 & 52 & 65 \\
\hline
\end{tabular}

Table 9: Share of the gifted student's mothers/fathers who gained the lower $(<)$, same $(=)$ and higher $(>)$ educational level than their parents

In other words, in the families of gifted students we observe not only the higher level of human capital in every generation, but which is even more important - the sound increase of it. Based on our dataset, we do not observe the Galtonian regression toward the mean.

\section{Human capital accumulation}

In this subchapter the human capital accumulation $H C_{0}^{*}$ and $L H C^{*}$ is measured using the expressions (5) and (6) on the scale from

- 0 (all family members finished just the elementary school)

- to 100 (all family members gained their $\mathrm{PhD}$ or its equivalent).

The average short-run human capital accumulation reaches $H C_{0}^{*}=55$ points for gifted students, $H C_{1}^{*}=41$ points for their mothers and $H C_{2}^{*}=37$ points for their fathers. The long-run human capital accumulation is therefore for the gifted students lower than short-run accumulation as it reaches $L H C^{*}=44$ points. These averages set out the landmarks with which we can compare all the results in this subchapter. The short run human capital accumulation of the gifted students and their mothers is moderately correlated $(\rho=0.41)$. The same is valid for the correlation of the human capital accumulation between gifted students and their fathers $(\rho=0.40)$ and between parents each other $(\rho=0.38)$. It means, that

- The higher level of human capital in the grandparental generation translates substantially to the higher level of the human capital of the gifted parents.

- Mothers from the families with higher level of the human capital tend to marriage men from the families with the higher level of the human capital as well.

If gifted children could read and write before entering their first class of elementary school, their short-run human capital is 61 points (significantly above-average); if they could not, it is only 52 points.

Gifted students who evaluated themselves as above-average from the elementary school have their short-run human capital of 57 points. Those, who underestimate themselves, have shortrun human capital about 45 points. This is in line with the findings, that children from the highly educated families exhibit greater degree of self-confidence.

The accumulation of the human capital is connected also to the factors of gifted student's success. Students, who do named talent as the main factor of their success, have short-run accumulated capital of 61 points. Those, who do no stress importance of the talent, have short-run accumulated capital of only 49 points. It means, that students from the families which are 'richer' in 
the human capital observe talent (which they cannot influence on their own) as very important. Similarly, gifted students who observe their family support as the crucial factor of their success has $H C_{0}^{*}=60$ and $\mathrm{LHC}=48$. On the other hand, students, who do not see their family as crucial for their success exhibit lower level of human capital accumulation: $H C_{0}^{*}=49$ and $L H C^{*}=41$.

Students, who see the roots of their success in the support of their teachers, exhibits lower short-run human capital accumulation $\left(H C_{0}^{*}=52\right.$ in comparison to $\left.H C_{0}^{*}=56\right)$.

Significant difference in the human capital accumulation level can be observed between students who attended 8-years grammar school and those who attended standard grammar school: $H C_{0}^{*}=64$ points in comparison to $H C_{0}^{*}=33$ points. Even this finding support the hypothesis, that children from the highly educated families are being send to elite secondary schools.

In ideal situation gifted children from the families which are poorer in the human capital, should be supported and influenced by their teachers. However, results of our research show, that gifted students, who were brought to their field by teachers, came from the families with higher human capital endowment ( $H C_{0}^{*}=59$ versus $H C_{0}^{*}=54$ points). Only those, who choose their filed on their own, came from families with substantially lower human capital endowment than their counterparts ( $H C_{0}^{*}=59$ versus $H C_{0}^{*}=52$ points).

Last but not least, we observe the extremely high level of human capital accumulation in the families where gifted students continue in the 'family field'. The human capital accumulation reached 58 points in the 'dynasties' but only 39 points in families in which the gifted student goes his or her own way.

\section{Discussion}

The crucial finding of our study suggests that the recognized gifted pupils and students come from the families with high stock of the accumulated human capital. This is in line with traditional model of intergenerational transmission mechanism as presented in Becker (1993) or Fischer and Lipovská (2013a and 2013b). Furthermore, Lundborg, Nordin and Rooth (2011) mentions, that there is a strong correlation between parent's human capital and the human capital of their children. Part of this transmission is according to the authors caused by the nurturing effect of the parental education on their children's education (ibidem).

Similarly as Lindahl et al. (2013) we find the studies on the twogeneration's transmission mechanism as insufficient. As well as in the case of Sweden, described in the Lindahl's study, even in the Czech Republic the education distribution has changed significantly. This transition was demonstrated by figures 2 and 3 .

Other reasons for the success of the gifted children from the families with high level of the human capital can be possibly found in the so called familism as explained by Durante, Labartion and Perotti (2011). In their research they discovered very high ratio of the academically successful students from the families active in the highest circles of academia. Durante, Labartion and Perotti focused just on the biggest Italian universities and they found there dozens of examples, when children, sons- and daughters-in-law, nephews and spouses were promoted during the mandates of their relatives serving as rectors or deans. This familism can have both the good as well as the bad effect. On the one hand, Durante, Labartion and Perotti suggest that it promotes efficiency of the allocation of the resources. On the other hand, Durante mentions that there might also Carnegi effect occurred: when children have confidence of their high academic position they do not work so hard and they possibly waste their human capital.

Sękowski and Siekańska (2008) studied the family background as well as the further career of

- 90 adults who once earned the national academic award prize and proved so their giftedness (focus group);

- 90 adults who reached no outstanding academic achievement (control group).

Their results are very similar to those of us. The most successful adults came from families of higher social and professional status. According to Sękowski and Siekańska nearly $16 \%$ of the gifted adult's father held doctoral degrees (in our dataset it is about $8 \%$ ), while just $1.1 \%$ of the fathers in the control group reached the same degree (among all the Czech man there is just $0.9 \%$ holders of the doctoral degree $)^{4}$.

Yet more similar are the results regarding the mothers of the gifted children. In the study of Sękowski and Siekańska $57 \%$ of the mother had a tertiary education, in our dataset the proportion was only slightly higher $(59 \%)$. On the other hand, the proportion of gifted only-children in our dataset (11\%) is much lower than in the Polish survey (43\%). Most of the Czech gifted children $(57 \%)$ had one brother or sister. ${ }^{5}$

We have shown that most of the gifted children attended the 8 -years grammar schools ( $60 \%$ on average). However, the same is truth for nearly $80 \%$ of children from families, where both parents have tertiary education, but only for $40 \%$ of children from the other families. This finding is in line with remarks of Matějů and Straková (2003) who suggest that parents with higher socioeconomic status are more interested in their child attending a selective school, and are willing to invest more energy to get such a child enrolled in such school.

Havigerová and Křováčková (2011) define exceptionally intellectually gifted children as children who could read, write and count when entering the first class of the elementary school. This is in line with our findings that most of the gifted children could read. However, only one third of the gifted children fulfilled such definition of exceptionally intellectually gifted who could read and wright.

We did not find sufficient evidence to support the Galtonian regression toward the mean. It can be caused by the fact, that while in the generation of grandparents the women had same or even higher level of human capital than men in $68 \%$ of cases, in the generation of parents this share increases to $75 \%$ cases. Furthermore, as we mentioned in the first subchapter, people with the higher education tend to marriage spouses with higher education as well.

\footnotetext{
$4 \quad$ The difference between Polish and Czech results can be caused also by the different perception of the doctoral degree.

5 It is interesting, that this structure is similar for both the Czech families where both parent has the tertiary education.
} 
An obvious weakness of our research is rooted in the dataset. Firstly, the number of respondents (213) is not very high. However, it is sufficient for the basic statistics. In the field of gifted pupil's research we must be often content with much less observations. For example conclusions of the study conducted by Mudrak and Zabrodska (2015) are based on just nine casestudies. Secondly, we did not and could not compare our results with two crucial control groups:

- $\quad$ normal (not gifted) children;

- children who are gifted but were not recognized as gifted.

Furthermore, as Rinn and Bishop (2015) recall, there is also the group of adults, who are not eminent, but where identified as gifted when they were children. We can summarize this problem in Table 10.

\begin{tabular}{|c|c|l|l|}
\hline \multicolumn{2}{|c|}{} & \multicolumn{2}{c|}{ Adult } \\
\cline { 3 - 4 } & $\begin{array}{c}\text { eminent } \\
\text { recognized as } \\
\text { gifted }\end{array}$ & $\begin{array}{l}\text { fully used po- } \\
\text { tential }\end{array}$ & $\begin{array}{l}\text { waste of the fi- } \\
\text { nancial capital }\end{array}$ \\
\hline \multirow{4}{*}{\begin{tabular}{c} 
Children \\
\cline { 2 - 4 }
\end{tabular}} & $\begin{array}{c}\text { not recognized } \\
\text { as gifted }\end{array}$ & $\begin{array}{l}\text { waste of the hu- } \\
\text { man capital }\end{array}$ & no gain, no loss \\
\hline
\end{tabular}

Table 10: Type I and type II errors in the gifted-support (source: own elaboration)

Ideally the giftedness of the children is recognized and further supported, so his or her potential is fully used. If the ambitious highly educated family supports gifted child who does not growth in the eminent adult, we witness so called Type I error (see e.g. Ary et al. 2010: 165). In such case the (financial) investments in the development of individual's human capital were purely wasted. Such case studies are described on the margin of the research conducted by Mudrak and Zabrodska (2015). In these cases the gifted children were forced by their parents and coaches to work hard on their human capital which leads them to changing their personal goals and career as soon as they were able to make decisions on their own.

However, the lack of care can lead to the Type II error, when the giftedness was not early recognized and hence supported. Children from the families with lower stock of the human capital who were not supported at least by their teachers, can end up as eminent adults, whose human capital was not developed sufficiently. Such a wasting of the human capital is comparable with the unemployment (e. g. Rinn and Bishop 2015).

\section{Conclusion}

Talented students are the most promising and most important part of our future human capital stock. However, there is still a profound ignorance of their family background, influences as well as the effect of schooling on their development and professional orientation.

In our study we offered original findings based on our own survey Talent 2016. We intend to conduct this survey every five years to monitor the changes in the structure of the Czech talent pool. This paper provides clear evidence of human capital intergenerational transmission as well as vertical immobility in the same generation. Most of the talented students came from the complete highly educated families with tradition in their field of interest and long positive attitudes toward accumulating the knowledge. On the other hand, the role of teachers in the support and guidance is negligible.
Premature reading and writing is often being considered as the sign of giftedness. We have shown that there is close relation between the gifted children premature reading ability and the accumulation of the human capital in their families. For example, if all six ancestors of the child gained the university degree, $82 \%$ of gifted students could read before entering the elementary school. The same is valid for the attendance of the 8 -years grammar schools.

Based on our dataset, we do not observe the Galtonian regression toward the mean. The vertical mobility in education was proved for $60 \%$ of student's mothers and $65 \%$ of fathers. Kind of 'dynasties' can be observed among the gifted children families. There is extremely high level of human capital accumulation in the families where gifted students continue in the 'family field'.

The family effect as well as the sex-dependency is incontestable. For the future economic growth and Czech well-being there must be offered a helping hand even for the so far unused talent pool of children with the less educated background as no country all over the world can afford to waste its valuable talent.

\section{Acknowledgements}

This work was written thanks to the long-term institutional support for the research development (IP 400040) of the Faculty of Informatics and Statistics of the University of Economics, Prague and was supported by the project of No. MUNI/A/0915/2015 funded by the Masaryk University.

\section{References}

Ary, D., Jacobs, L. C., Razavieh, A. and Sorensen, C. K. (2010) Introduction to research in education, 8th edition, Belmont, CA: Wadsworth.

Becker, G. S. (1993) Human Capital: A Theoretical and Empirical Analysis with Special Reference to Education, London: The University of Chicago Press.

Benos, N. and Karagiannis, S. (2016) 'Do education quality and spillovers matter? Evidence on human capital and productivity in Greece', Economic Modelling, Vol. 54, pp. 563-573. http:// dx.doi.org/10.1016/j.econmod.2016.01.015

Black, S. E., Devereux, P. J., Salvanes, K. G. (2003) Why the apple doesn't fall far: understanding intergenerational transmission of human capital, IZA Discussion paper series, No. 926. Botsch, R. (2011) Scopes and Methods of Political Science: Chapter 12 [online]. Available: http://www.usca.edu/polisci/ apls301/Text/Chapter\%2012.\%20Significance $\% 20$ and $\% 20$ Measures\%20of\%20Association.htm [02 May 2016]

Brian, K. (2007). Human Capital: How what you know shapes your life, Paris: Organisation for Economic Co-operation and Development [online]. Available: https://www.oecd.org/insights/humancapitalhowwhatyouknowshapesyourlife.htm [02 Aug 2016]

Budíková, M., Králová M. and Maroš, B. (2010). Průvodce základními statistickými metodami [Guide to basic statistical methods], Prague: Grada Publishing, a. s.

Callard-Szulgit, R. D. (2012) Perfectionism and Gifted Children, 2nd edition, R\&L Education.

CZSO (2014) Úroveň vzdéláni obyvatelstva podle výsledku scítáni lidu [The education level of the population according to census results], Prague, Publication code 170232-14 [online]. Available: https://www.czso.cz/csu/czso/uroven-vzdelani-obyvatelstva-podle-vysledku-scitani-lidu-2011-xllg5xjb8q [02 Aug 2016]

Act no. 103/2014 Coll. amending Act no. 73/2005 Coll., on the 
education of children, pupils and students with special educational needs and exceptionally gifted.

Durante, R., Labartion, G. and Perotti, R. (2011) Academic Dynasties: Decentralization and Familism in the Italian Academia. NBER Working Paper Series, WP 17572.

Entler, E., Sosnovec, L., Šecl, V. (2008) Umi školy pracovat s nadanými žáky? [Can the schools work with the gifted pupils?], Prague, Czech Schooling Inspection - Thematic report.

Ermisch, J. and Pronzato, Ch. (2010) 'Causal Effects of Parent's Education on Children's Education', ISER Working Paper Series.

Fischer, J. and Lipovská, H. (2013a) 'How Does the Parent's Attained Level of Education Influence Lifelong Learning of Children?' Efficiency and Responsibility in Education: 10th International Conference. Prague, pp. 128-135.

Fischer, J. and Lipovská, H. (2013b) 'Building Human Capital: The Impact of Parents' Initial Educational Level and Lifelong Learning on Their Children', Journal on Efficiency and Responsibility in Education and Science, Vol. 6, No. 4, pp. 134-142. http://dx.doi.org/10.7160/eriesj.2013.060402

Gallardo-Gallardo, E., Dries, N. and González-Cruz, T. F. (2013) 'What is the meaning of 'talent' in the world of work?', Human Resource Management Review, Vol. 23, No. 4, pp. 290-300. http://dx.doi.org/10.1016/j.hrmr.2013.05.002

Hartl, P. and Hartlová, H. (2000) Psychologický slovník [A Dictionary of Psychology], Prague: Portál.

Havigerová, J. M. and Křováčková, B. (2011) Co bychom méli vědět o nadání [What should we know about talent], Hradec Králové: Gaudeamus.

Hř́bková, L. (2009) Nadání a nadani: pedagogicko-psychologické prístupy, modely, výzkumy a jejich vztah ke školské praxi [Gifts and talents: Pedagogical-psychological approaches, models, research, and their relationship to educational practice], Prague: Grada Publishing, a. s.

Jackson, S. L. (2008) Research methods and statistics: a critical thinking approach, Australia: Heinle Cengage Learning.

Kell, H. J., Lubinski, D. and Benbow, C. P. (2013) 'Who Rises to the Top? Early Indicators.' Psychological Science, Vol. 24, No. 5, pp. 648-659. http://dx.doi.org/10.1177/0956797612457784 Lipovská, H. and Fischer, J. (2016) 'Talented students and their family background' Efficiency and Responsibility in Education: 13th International Conference. Prague, pp. 319-326.

Lindahl, M., Palme, M., Massih, S. S. and Sjögren, A. (2013) 'Long-term intergenerational persistence of human capital: an empirical analysis of four generations' Department of Economics, Stockholm University, Working Paper 2013:3.

Lundborg, P., Nordin, M. and Rooth, D. O. (2011) 'The Intergenerational Transmission of Human Capital: Exploring the Role of Skills and Health Using Data on Adoptees and Twins', IZA Discussion Paper no. 6099.

Makel, M. C., Snyder, K. E., Thomas, C., Malone, P. S. and Putallaz, M. (2015) 'Gifted Students' Implicit Beliefs About Intelligence and Giftedness.' Gifted Child Quarterly, Vol. 59, No. 4, pp. 203-212. http://dx.doi.org/10.1177/0016986215599057 Matějů, P. and Straková, J. (2003) 'Role rodiny a školy v reprodukci vzdělanostních nerovností. Sociologický pohled na úlohu víceletých gymnázií ve světle výzkumu PISA 2000.' [Role of the family and school in the reproduction of educational inequalities. Sociological view to the role of the grammar school in the light of PISA 2000 survey] Sociologický časopis - Czech Sociological Review, Vol. 39, No. 5, pp. 625-652.

Matějů, P. (2006) Nerovné šance na vzděláni-hlavní závěry z vydané monografie [Unequal educational opportunities-the main conclusions from the published monograph]. Socioweb
7 [online]. Available: http://www.socioweb.cz/index.php@ disp=teorie \&shw=236\&lst=106.html [02 Aug 2016]

Mazouch, P. and Fischer, J. (2011) Lidský kapitál. Měření, souvislosti, prognózy [Human Capital - measuring, context, projections], Prague: C. H. Beck.

Morkes, F. (2010) 'Proměny povinné školní docházky' [Metamorphosis of the compulsory education] Ucitelské noviny, 33/2010 [online]. Available: http://www.ucitelskenoviny. cz/?archiv\&clanek=5492 [02 Aug 2016]

Mudrak, J. and Zabrodska, K. (2014) 'Childhood Giftedness, Adolescent Agency: A Systemic Multiple-Case Study.' Gifted Child Quarterly, Vol. 59, No. 1, pp. 55-70. http://dx.doi. org/10.1177/0016986214559602.

Pavlát, J. (2011) 'Dlouhodobé následky rozvodu pro děti.' [Long-term Consequences of Divorce] Česká a slovenská psychiatrie, Vol. 107, No. 5, pp. 297-300.

Rinn, A. N. and Bishop, J. (2015) 'Gifted Adults: A Systematic Review and Analysis of the Literature.' Gifted Child Quarterly, Vol. 59, No. 4, pp. 213-235. http://dx.doi.org/10.1177/0016986215600795.

Sarsons, H. and Xu, G. (2015) 'Confidence Men? Gender and Confidence: Evidence among Top Economists'. In print.

Sękowski A., Siekańska M. (2008) 'National Academic Award Winners over Time: Their Family Situation, Education and Interpersonal Relations', High Ability Studies, Vol. 19, No. 2, pp. 155-171.

Senn, S. (2011) 'Francis Galton and regression to the mean', Significance, Vol. 8, No.3, pp. 124-126.

Sewell, S. and Shah, V. P. (1968) 'Parents' Education and Children's Educational Aspirations and Achievements', American Sociological Review, Vol. 33, No. 2, pp. 191-209.

Winner, E. (1997) Gifted Children: Myths and Realities, Basic Books.

Yang, J. and Qiu, M. (2016) 'The impact of education on income inequality and intergenerational mobility', China Economic Review, Vol. 37, pp. 110-125. http://dx.doi.org/10.1016/j. chieco.2015.12.009.

Yeung, R. (2014) 'Gifted Education: Robin Hood or the Sheriff of Nottingham?' Education and Urban Society, Vol. 46, No. 7, pp. 798-825. http://dx.doi.org/10.1177/0013124512470162. 